\title{
Soil Stabilization Using Waste Shredded Rubber Tyre Chips
}

\author{
Ghatge Sandeep Hambirao ${ }^{1}$ Dr.P.G.Rakaraddi ${ }^{2}$ \\ PG Student, Department of Civil EngineeringBasaveshwar Engineering College, Bagalkot-587102, India \\ Professor, Department of Civil EngineeringBasaveshwar Engineering College, Bagalkot-587102, India
}

\begin{abstract}
Construction of engineering structures on weak or soft soil is considered as unsafe. Improvement of load bearing capacity of the soil may be undertaken by a variety of ground improvement techniques. In the present investigation, shredded rubber from waste has been chosen as the reinforcement material and cement as binding agent which was randomly included into the soil at three different percentages of fibre content, i.e. 5\% $10 \%$ and $15 \%$ by weight of soil. The investigation has been focused on the strength behaviour of soil reinforced with randomly included shredded rubber fibre. The samples were subjected to California bearing ratio and unconfined compression tests. The tests have clearly shown a significant improvement in the shear strength and bearing capacity parameters of the studied soil. The results obtained are compared with unreinforced samples and inferences are drawn towards the usability and effectiveness of fiber reinforcement as a replacement for deep or raft foundation and on pavement subgrade soil as a cost effective approach. The low strength and high compressible soft clay soils were found to improve by addition of shredded rubber and cement. It can be concluded that shredded rubber fibre can be considered as a good earth reinforcement material.
\end{abstract}

Key words: black cotton soil, California bearing ratio test, shedi soil, tyre chips, unconfined compression test.

\section{Introduction}

Solid waste management is one of the major environmental concerns worldwide. In India, the scrap tyres are being generated and accumulated in large volumes causing an increasing threat to the environment. In order to eliminate the negative effect of these depositions and in terms of sustainable development, there is great interest in the recycling of these non-hazardous solid wastes. The potential of using rubber from worn tyres in many civil engineering works has been studied for more than 30 years. Applications where tyres can be used have proven to be effective in protecting the environment and conserving natural resources. In recent times with the increase in the demand for infrastructure and feasible foundation design in not applicable due to poor bearing capacity of ground soil stabilization has started to take a new shape. Stabilization is process of fundamentally changing the chemical properties of soft soils by adding binders or stabilizers, either in wet or dry conditions to increase the strength and stiffness of the originally weak soils(Yilmez and Degirmenci,[1]; Lee and Lee,[2]). With the availability of better research, materials and equipment soil stabilization is emerging as a popular and cost-effective method for soil improvement. With the availability of better research, materials and equipment soil stabilization is emerging as a popular and cost-effective method for soil improvement.

In the present investigation attempt is made to stabilize black cotton soil and shedi soil. Black cotton is collected from Vidyagiri area of Bagalkot city and shedi soil is collected from Haliyal road of Dharwad city area with randomly distributed shredded rubber tyre chips with 5\%, 10\%, 15\% and cement with $2 \%$ and $4 \%$ percentage. The unconfined and CBR tests were carried out in the laboratory for different mix proportions of rubber with black cotton soil and shedi soil. Considerable improvement is found in strength of black cotton and shedi soil for the $5 \%$ percent mix of rubber.

\section{Soil reinforcement}

Reinforcement is an effective and reliable technique for increasing strength and stability of soils. In general soil reinforcements can be classified into two major categories (by their stiffness): (1) ideally inextensible and (2) ideally extensible inclusions. The former includes high modulus metal strips and bars, while the latter includes relatively low modulus natural and synthetic fibers, plant roots and polymer fabric and shredded tyre chips.

\section{Cement stabilization}

When cement is mixed with soil, generally there will be reduction in liquid limit, plastic limit and the potential for volume change of soils (Bell [3]). But there will be increase in the shrinkage limit and shear strength. The increase in strength of cement treated soil is by primary and secondary cementations reactions in the soil cement matrix. The primary cementation is due to hydration products of Portland cement. A variety of compounds and gels are formed by hydration reaction (Chen and Wong [4]). The Portland cement is a heterogeneous substance containing tricalcium silicate $\left(\mathrm{Ca}_{3} \mathrm{~S}\right)$, dicalcium silicate $\left(\mathrm{Ca}_{2} \mathrm{~S}\right)$, tricalcium aluminate 
$\left(\mathrm{Ca}_{3} \mathrm{~A}\right)$ and tetra calcium alumino-ferrite $\left(\mathrm{Ca}_{4} \mathrm{AF}\right)$. The compounds in the Portland cement are transformed on addition of water. Hydration of cement occurs and major hydration products are formed when the pore water of the soil comes in contact with cement. The products are hydrated calcium silicates, hydrated calcium aluminates and hydrated lime (Croft, J.B [5]; Al-Rawas, et al., [6]). The first two of the hydrated products are the main cementations products and the hydrated lime is deposited as a separate phase. A hardened skeleton matrix is formed when these cement particles bind the adjacent cement grains together and encloses the unaltered particles. The silicate and aluminate phases are internally mixed and may not completely crystalline. The hydration products induce cementation between the soil particles when cement content is sufficiently high. Part of calcium hydroxide may also be mixed with other hydrated phase. In addition to primary reaction process there is also secondary phase between the liberated calcium hydroxide and alumina and silica of soil clay that leads to the formation of additional calcium silicate hydrates and calcium aluminate hydrates. The pozzolanic reaction increases the $\mathrm{pH}$ (Peech [7]) of pore water due to the dissolution of the hydrated lime and the strong base dissolves soil silica and alumina from clay minerals. The hydrous silica and alumina slowly react with calcium ions liberated from hydrolysis of cement to form insoluble compounds that harden on curing to stabilize the soil.

\subsection{Black cotton soil}

\section{Materials And Methodology}

Black cotton soil is collected from $1 \mathrm{~m}$ below ground level at Vidyagiri area of Bagalkot city, Karnataka state. The Latitude and Longitude of the area is $16^{\circ} 12^{\prime} 0 \mathrm{~N}$ and $75^{\circ} 45^{\prime} 0 \mathrm{E}$ respectively. Index, physical and engineering properties are given in the table 1 .

\subsection{Shedi soil}

Shedi soils are commonly found in south-west coastal belt in India. Shedi soil is collected from Halyal road of Dharwad city Karnataka state with Latitude $15^{\circ} 28^{\prime} \mathrm{N}$ and Longitude $75^{\circ} 1^{\prime} \mathrm{E}$.Index, physical and engineering properties are given in the table 1.

Table1. Index, physical and engineering properties of soils

\begin{tabular}{|c|c|c|}
\hline Properties & Site A & Site B \\
\hline Colour when dry & Black & Yellow \\
\hline Specific gravity $(G)$ & 2.60 & 2.34 \\
\hline Atterberg limits; & & \\
Liquid limit $w_{L}(\%)$ & 54.09 & 49.40 \\
Plastic limit $w_{P}(\%)$ & 33.22 & 27.93 \\
Plasticity index $I_{P}(\%)$ & 10.87 & 22.10 \\
\hline I.S classification & MI & CI \\
\hline Compaction characteristics & & \\
Maximum dry density, $\gamma_{\text {dmax }}\left(\mathrm{gm} / \mathrm{cm}^{3}\right)$ & 1.37 & 2.34 \\
Optimum moisture content, $w_{O M C}(\%)$ & 29.29 & 16.40 \\
\hline Grain size distribution & & \\
Gravel and sand $(\%)$ & 19.90 & 40.86 \\
Silt and Clay $(\%)$ & 80.10 & 59.14 \\
\hline California bearing ratio $(\%)$ & 15.00 & 59.40 \\
\hline Unsoaked & & \\
Soaked & 2.03 & 3.24 \\
\hline
\end{tabular}

\subsection{Cement}

An Ordinary Portland Cement (OPC) of 53 grade has been used for treatment of the selected soil in order to modify its properties such as unconfined compressive strength and California bearing ratio.

Table 2 Physical requirements of the OPC 53 grade cement are as follows.

\begin{tabular}{|c|c|c|}
\hline Sl. No & Physical properties & Range \\
\hline 1 & Fineness $\left(\mathrm{m}^{2} / \mathrm{kg}\right)$ & 330 \\
\hline 2 & Standard Consistency $(\%)$ & 30.5 \\
\hline 3 & Initial setting time(min.) & 150 \\
\hline 4 & Final setting time(minutes) & 225 \\
\hline
\end{tabular}

\subsection{Shredded tyre rubber}

Shredded tyre material was obtained from the waste generated from tyre re-threading industries at Dharwad. The shredded tyre material used is of size $10 \mathrm{~mm}$ to $25 \mathrm{~mm}$ in length. The shreds have a thickness 
ranging from 2 to $3 \mathrm{~mm}$ and they don't contain any steel wire or nylon fibres. Specific gravity of tyre shreds obtained with a pycnometer test ranges from 0.90 to 1.12 .

\section{Experimental Methods \\ 3.1 Preparation of specimens for unconfined compressive strength test.}

The soil passing through $425 \mu$ sieve is mixed with varying percent of cement i.e. $2 \%$, and $4 \%$ cured for 4, 7, 14days soil samples are prepared with different percentage i.e. $0 \%, 5 \%, 10 \%$, and $15 \%$ of shredded rubber chips at optimum water content total forty eight samples were prepared. The maximum dry density $\left(M D D, \gamma_{d m a x}\right)$ and optimum moisture content $(O M C)$ for the soil-shredded rubber mix is determined from standard Proctor test as per IS: 2720, Part VII- 1980. Soil is mixed with cement and rubber shreds with optimum amount of water for the mix as obtained from standard proctor test. The samples were prepared by dynamic compaction method. The molding device consists of a steel tube with internal diameter of $34 \mathrm{~mm}$ and height $70 \mathrm{~mm}$. These prepared soil specimens are kept for curing ages of 4, 7 and 14 days in desiccators.

\subsection{Testing of specimen for unconfined compressive strength test.}

The unconfined compressive strength test is conducted in accordance with IS 2720 part X, 1991. The specimen is placed on bottom plate of loading device the bottom plate is adjusted to make contact with the specimen. Force is applied so as to produce an axial strain rate of 0.5 to 2 percent $/ \mathrm{min}$, as per IS 2720 part X, 1991 to the specimen until the shear failure or until a vertical deformation of $20 \%$ is reached. Displacement is measured by strain gauge. Finally compressive strength is calculated based on failure load and corrected area.

\subsection{Preparation of specimens for California bearing ratio test.}

First soil is kept for air drying then it is mixed directly mixed with stabilizing agent with different percentages of cement i.e. $2 \%$ and $4 \%$ with shredded rubber chips of 5, 10, and 15 percent at optimum water content $(O M C)$. The maximum dry density $\left(M D D, \gamma_{d m a x}\right)$ and optimum moisture content $(O M C)$ for the soilshredded rubber mix is determined from standard Proctor tests. Tests were carried out in soaked and unsoaked condition. The samples were prepared by dynamic compaction method. The mould consists internal diameter of $150 \mathrm{~mm}$ and height $175 \mathrm{~mm}$, collar is of $50 \mathrm{~mm}$ height. The unsoaked samples are cured in with wet gunny bags to facilitate hydration of cement. Unsoaked samples are cured for 4, 7 and 14 days so that the room temperature is maintained. Soaked samples are cured in water tank for curing ages of 4, 7 and 14 days which allows free access of water from top and bottom.

\subsection{Testing of soil samples for California bearing ratio test.}

The California bearing ratio test is conducted is in accordance with IS 2720 part XVI, 1987. The loading frame is with loading capacity of five tonnes provided with proving ring and a dial gauge reading to $0.01 \mathrm{~mm}$. Soil samples are placed on bottom plate of loading device the base plate. Annular surcharge weight equal intensity of base material and the pavement is placed to prevent upheaval of soil. Load is applied at a strain rate of $1.25 \mathrm{~mm} / \mathrm{min}$, as per IS 2720 part XVI, 1987.Penetration is measured by strain gauge. Load is recorded at the penetration of $0.0,0.5,1.5,2.0,2.5,3.0,4.0,5.0,7.5,10.0$ and $12.5 \mathrm{~mm}$. $C B R$ value is expressed as a percentage of the actual load causing the penetrations of $2.5 \mathrm{~mm}$ or $5.0 \mathrm{~mm}$ to the standard loads. The greatest value calculated for penetrations at $2.5 \mathrm{~mm}$ and $5.0 \mathrm{~mm}$ will be recorded as the $C B R$.

The California bearing ratio is calculated as follows:

California bearing ratio $(\mathrm{C} . \mathrm{B} \cdot \mathrm{R})=\frac{\mathrm{Pt}}{\mathrm{Ps}} \mathrm{x} 100$

Where,

$\mathrm{Pt}=$ corrected test load corresponding to the chosen penetration from the load penetration curve

Ps $=$ standard load for the same depth of penetration

\section{Results And Discussions}

Unconfined Compressive Strength Tests and California bearing ratio tests are conducted for black cotton soil and shedi soil with $2 \%$ and $4 \%$ cement with the varying rubber percentage i.e $0 \%, 5 \%, 10 \%$ and $15 \%$ and the results were noted and compared as shown in the tables and figs.

The given below typical graphs of unconfined compressive strength shows variation of unconfined compressive strength and California bearing ratio test shows the variation of California bearing ratio both soaked and unsoaked for curing period of 4,7 and 14 days with the addition of $2 \%$ and $4 \%$ cement. 


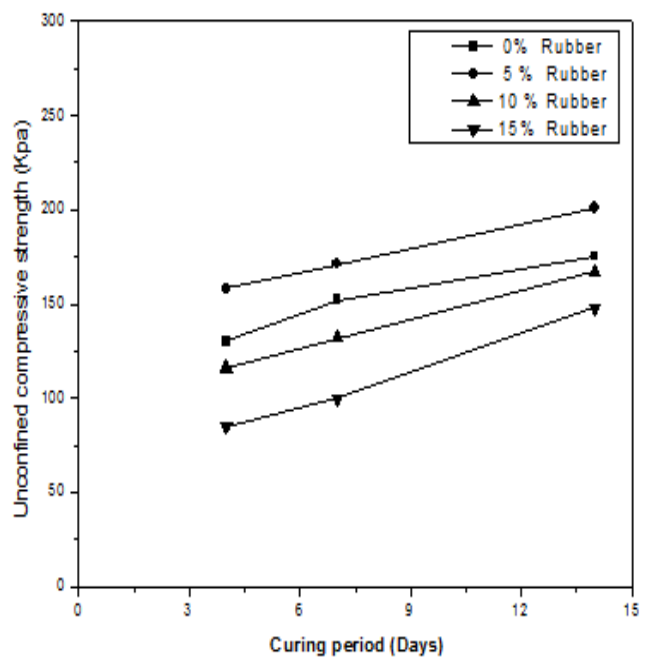

(a)

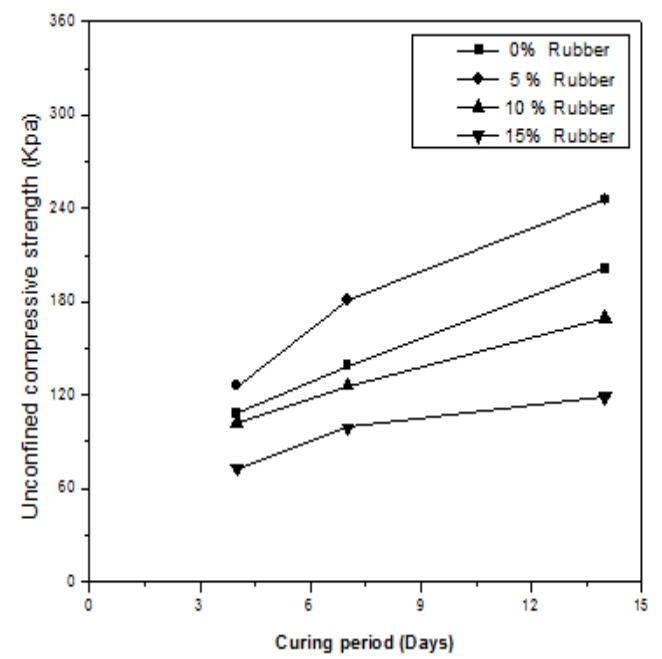

(b)

Fig 1shows the variation of unconfined compressive strengthfor curing period of 4, 7 and 14 days on (a) shedi soil with the addition of $2 \%$ cement and (b)black cotton soil with the addition of $4 \%$ cement respectively.
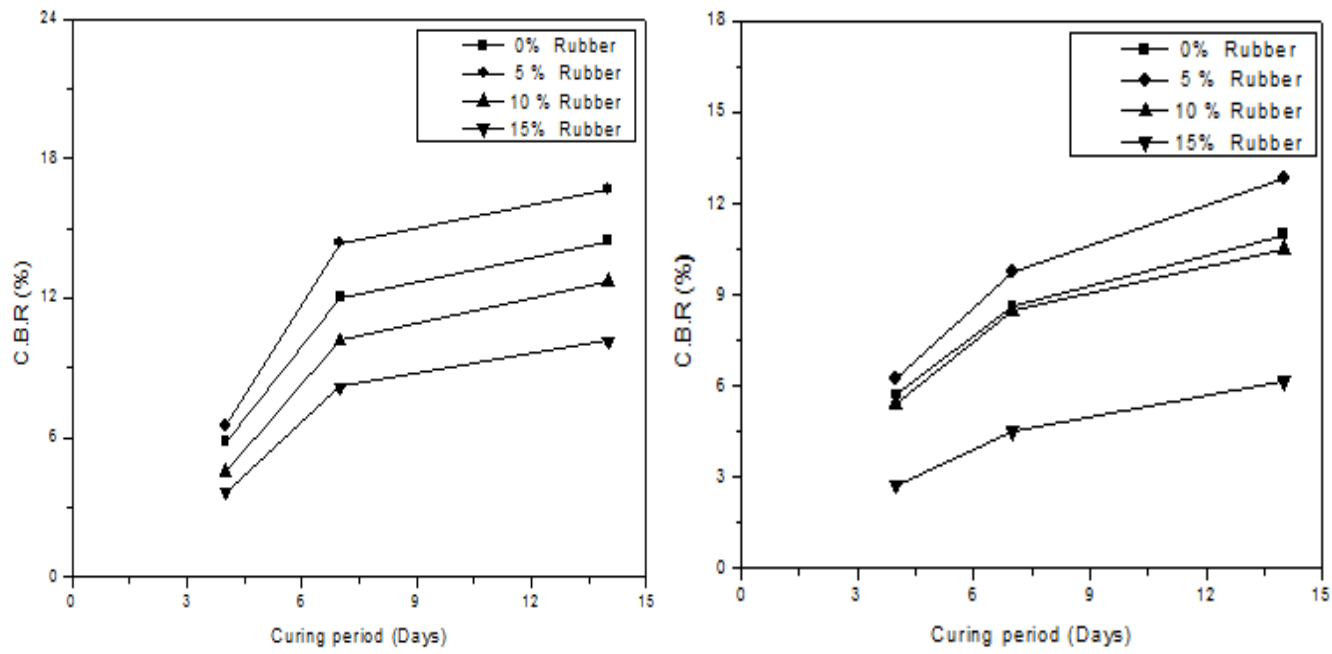

(a) (b)

Fig 2 shows the variation of California bearing ratio (unsoaked) for curing period of 4, 7 and 14 days on (a)shedi soil with the addition of $2 \%$ cement and (b) black cotton soil with the addition of $4 \%$ cement respectively.
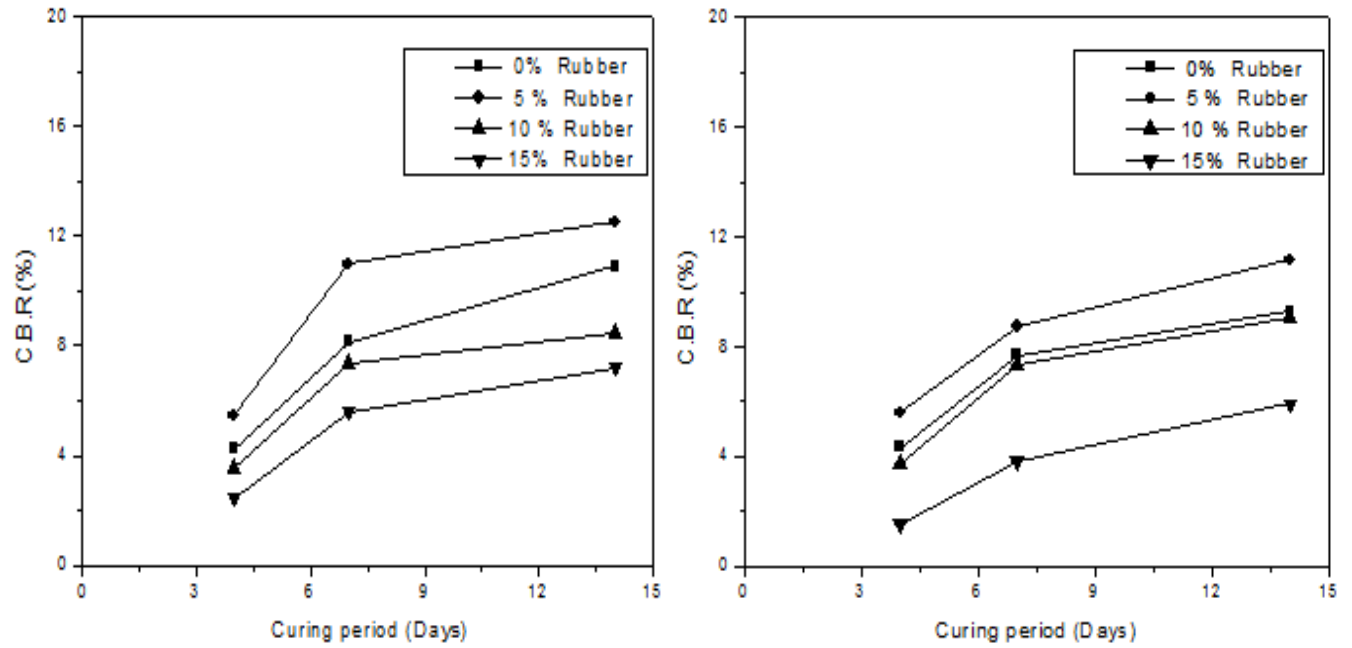

(a) (b)

Fig 3 shows the variation of California bearing ratio (soaked) for curing period of 4,7 and 14 days on (a) shedi soil with the addition of $2 \%$ cement and (b)black cotton soil with the addition of $4 \%$ cement respectively. 


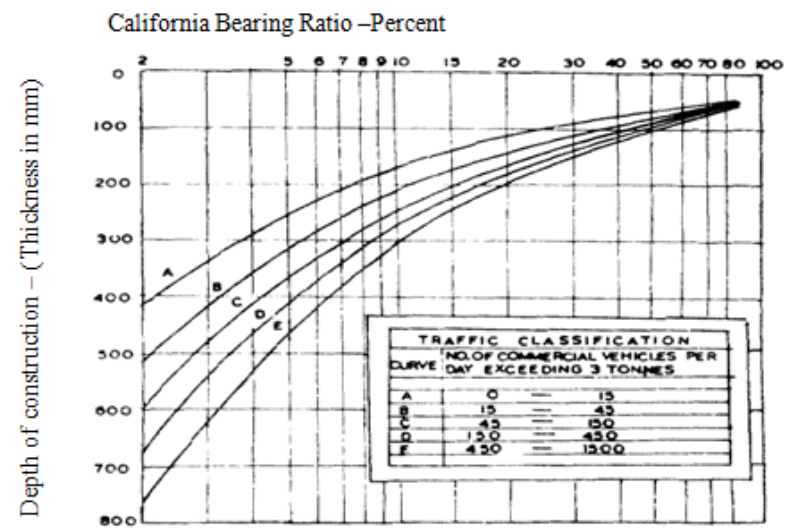

Fig4 shows pavement thickness design chart (Recommended by IRC)

Table 3.Classification of traffic for design.

\begin{tabular}{|c|c|}
\hline Traffic (commercial vehicles per day) & CBR design curves applicable \\
\hline $0-15$ & $\mathrm{~A}$ \\
\hline $15-45$ & $\mathrm{C}$ \\
\hline $45-150$ & $\mathrm{D}$ \\
\hline $150-450$ & $\mathrm{E}$ \\
\hline $450-1500$ & \\
\hline
\end{tabular}

Table 4 shows unconfined compressive strength test results for black cotton soil and shedi soil with $2 \%$ and $4 \%$ cement.

\begin{tabular}{|c|c|c|c|c|c|c|c|c|c|c|c|c|}
\hline \multirow{5}{*}{$\begin{array}{c}\text { Rubber } \\
\text { content } \\
(\%)\end{array}$} & \multicolumn{12}{|c|}{ Unconfined compressive strength, $q_{u}(\mathrm{kPa})$} \\
\hline & \multicolumn{6}{|c|}{ Black cotton soil } & \multicolumn{6}{|c|}{ Shedi soil } \\
\hline & \multicolumn{3}{|c|}{$2 \%$ cement } & \multicolumn{3}{|c|}{$4 \%$ cement } & \multicolumn{3}{|c|}{$2 \%$ cement } & \multicolumn{3}{|c|}{$4 \%$ cement } \\
\hline & \multicolumn{3}{|c|}{ Curing periods in days } & \multicolumn{3}{|c|}{ Curing periods in days } & \multicolumn{3}{|c|}{ Curing periods in days } & \multicolumn{3}{|c|}{ Curing periods in days } \\
\hline & 4 days & $\begin{array}{c}7 \\
\text { days }\end{array}$ & $\begin{array}{c}14 \\
\text { days }\end{array}$ & $\begin{array}{c}4 \\
\text { days }\end{array}$ & $\begin{array}{c}7 \\
\text { days }\end{array}$ & $\begin{array}{c}14 \\
\text { days }\end{array}$ & $\begin{array}{c}4 \\
\text { days }\end{array}$ & $\begin{array}{c}7 \\
\text { days }\end{array}$ & $\begin{array}{c}14 \\
\text { days }\end{array}$ & $\begin{array}{c}4 \\
\text { days }\end{array}$ & $\begin{array}{c}7 \\
\text { days }\end{array}$ & $\begin{array}{c}14 \\
\text { days }\end{array}$ \\
\hline $\mathbf{0}$ & 26 & 45 & 67 & 102 & 139 & 201 & 130 & 152 & 175 & 215 & 249 & 264 \\
\hline 5 & 36 & 50 & 74 & 126 & 181 & 246 & 158 & 171 & 201 & 230 & 278 & 328 \\
\hline 10 & 22 & 37 & 63 & 108 & 126 & 169 & 116 & 132 & 167 & 183 & 206 & 209 \\
\hline 15 & 12 & 16 & 44 & 73 & 99 & 119 & 85 & 100 & 148 & 154 & 167 & 176 \\
\hline
\end{tabular}

Table 5 shows California bearing ratio test results for black cotton soil and shedi soil with $2 \%$ and $4 \%$ cement (unsoaked).

\begin{tabular}{|c|c|c|c|c|c|c|c|c|c|c|c|c|}
\hline \multirow{5}{*}{$\begin{array}{c}\text { Rubber } \\
\text { content } \\
(\%)\end{array}$} & \multicolumn{12}{|c|}{ California bearing ratio $(\%)$} \\
\hline & \multicolumn{6}{|c|}{ Black cotton soil } & \multicolumn{6}{|c|}{ Shedi soil } \\
\hline & \multicolumn{3}{|c|}{$2 \%$ cement } & \multicolumn{3}{|c|}{$4 \%$ cement } & \multicolumn{3}{|c|}{$2 \%$ cement } & \multicolumn{3}{|c|}{$4 \%$ cement } \\
\hline & \multicolumn{3}{|c|}{ Curing periods in days } & \multicolumn{3}{|c|}{ Curing periods in days } & \multicolumn{3}{|c|}{ Curing periods in days } & \multicolumn{3}{|c|}{ Curing periods in days } \\
\hline & $\begin{array}{c}4 \\
\text { days }\end{array}$ & $\begin{array}{c}7 \\
\text { days } \\
\end{array}$ & $\begin{array}{c}14 \\
\text { days }\end{array}$ & $\begin{array}{c}4 \\
\text { days }\end{array}$ & $\begin{array}{c}7 \\
\text { days }\end{array}$ & $\begin{array}{c}14 \\
\text { days }\end{array}$ & $\begin{array}{c}4 \\
\text { days }\end{array}$ & 7 days & $\begin{array}{c}14 \\
\text { days }\end{array}$ & 4 days & 7 days & $\begin{array}{c}14 \\
\text { days }\end{array}$ \\
\hline $\mathbf{0}$ & 2.09 & 2.28 & 3.98 & 5.71 & 8.6 & 10.97 & 5.82 & 12.04 & 14.45 & 7.09 & 16.29 & 19.09 \\
\hline 5 & 3.15 & 3.28 & 4.33 & 6.26 & 9.76 & 12.83 & 6.52 & 14.36 & 16.68 & 8.36 & 18.04 & 21.06 \\
\hline 10 & 2.16 & 2.67 & 3.21 & 5.45 & 8.49 & 10.51 & 4.53 & 10.18 & 12.75 & 6.43 & 14.97 & 18.74 \\
\hline 15 & 1.24 & 1.57 & 1.88 & 2.75 & 4.53 & 6.17 & 3.67 & 8.18 & 10.16 & 4.12 & 10.86 & 14.01 \\
\hline
\end{tabular}


Table 6 shows California bearing ratio test results for black cotton soil and shedi soil with $2 \%$ and $4 \%$ cement (soaked).

\begin{tabular}{|c|c|c|c|c|c|c|c|c|c|c|c|c|}
\hline \multirow{5}{*}{$\begin{array}{c}\text { Rubber } \\
\text { content } \\
(\%)\end{array}$} & \multicolumn{12}{|c|}{ California bearing ratio (\%) } \\
\hline & \multicolumn{6}{|c|}{ Black cotton soil } & \multicolumn{6}{|c|}{ Shedi soil } \\
\hline & \multicolumn{3}{|c|}{$2 \%$ cement } & \multicolumn{3}{|c|}{$4 \%$ cement } & \multicolumn{3}{|c|}{$2 \%$ cement } & \multicolumn{3}{|c|}{$4 \%$ cement } \\
\hline & \multicolumn{3}{|c|}{$\begin{array}{c}\text { Curing periods in } \\
\text { days }\end{array}$} & \multicolumn{3}{|c|}{ Curing periods in days } & \multicolumn{3}{|c|}{ Curing periods in days } & \multicolumn{3}{|c|}{ Curing periods in days } \\
\hline & $\begin{array}{c}4 \\
\text { days }\end{array}$ & $\begin{array}{c}7 \\
\text { days }\end{array}$ & $\begin{array}{c}14 \\
\text { days }\end{array}$ & $\begin{array}{c}4 \\
\text { days }\end{array}$ & $\begin{array}{c}7 \\
\text { days }\end{array}$ & $\begin{array}{c}14 \\
\text { days }\end{array}$ & $\begin{array}{c}4 \\
\text { days }\end{array}$ & 7 days & $\begin{array}{c}14 \\
\text { days }\end{array}$ & 4 days & 7 days & $\begin{array}{c}14 \\
\text { days }\end{array}$ \\
\hline $\mathbf{0}$ & 1.57 & 1.96 & 2.36 & 4.33 & 7.7 & 9.28 & 4.24 & 8.14 & 10.9 & 5.05 & 9.85 & 11.12 \\
\hline 5 & 2.23 & 2.36 & 2.93 & 5.58 & 8.73 & 11.16 & 5.45 & 10.97 & 12.52 & 6.35 & 12.04 & 13.79 \\
\hline 10 & 1.48 & 1.64 & 1.88 & 3.72 & 7.35 & 9.05 & 3.54 & 7.35 & 8.45 & 4.2 & 8.23 & 9.94 \\
\hline 15 & 1.11 & 1.24 & 1.37 & 1.51 & 3.81 & 5.91 & 2.45 & 5.6 & 7.22 & 3.72 & 6.39 & 7.75 \\
\hline
\end{tabular}

\subsection{Unconfined compressive strength test for black cotton soil and shedi soil with $2 \%$ and $4 \%$ cement.}

From the table 4 and fig 1 it is clearly known that for $2 \%$ cement, maximum unconfined compressive strength at the rubber content of 5\% and curing period of 14 days for black cotton soil is $74 \mathrm{kPa}$ where as for shedi soil it is $201 \mathrm{kPa}$. Similarly From the table 4 and fig1 it is noted that with addition of $4 \%$ cement for $5 \%$ rubber content and curing period of 14 days maximum unconfined compressive strength for black cotton soil is $246 \mathrm{kPa}$ where as for shedi soil it is $328 \mathrm{kPa}$. This indicates that the increase in the curing period leads to an increase the unconfined compressive strength at an optimum mix of 5\% shredded rubber. This indicates that there is an increase in the stiffness of the stabilized soil is not only due to the hydration of cement with time but optimum rubber content. The observed results are well matching with the results of(Meei-Hoan Ho and CheeMing Chan[8]).

\subsection{California bearing ratio test for black cotton soil and shedi soil with $2 \%$ and $4 \%$ cement (unsoaked).}

The maximum California bearing ratio for $2 \%$ cement content at the rubber content of $5 \%$ and curing period of 14 days for black cotton soil is $4.33 \%$ where as for shedi soil it is $16.68 \%$. This can be observed in the table 5 and fig 2 and from the same table 5 and fig 2 it is also noted that at the rubber content of $5 \%$ for $4 \%$ cement and curing period of 14 days, maximum California bearing ratio for black cotton soil is $12.83 \%$ where as for shedi soil it is $21.06 \%$. This indicates that the increase in the curing period leads to increase in California bearing ratio at an optimum mix of 5\% shredded rubber. This indicates that there is an increase in the bearing capacity of the stabilized soil is not only due to the hydration of cement with time but optimum rubber content. Similar results were reported by (KoteswaraRao et al.,[9]).

\subsection{California bearing ratio test results (soaked) for black cotton soil and shedi soil with $2 \%$ and $4 \%$ cement}

Table 6 and fig 3 it is noted that for $2 \%$ cement at rubber content of $5 \%$ and curing period of 14 days the maximum California bearing ratio for black cotton soil is $2.93 \%$ where as for shedi soil it is $12.52 \%$ when it is soaked. Similarly $4 \%$ cement content at the rubber content of $5 \%$ and curing period of 14 days for black cotton soil is $11.16 \%$ where as for shedi soil it is $13.79 \%$.This indicates that the increase in the curing period leads to an increase in California bearing ratio the at an optimum mix of 5\% shredded rubber. This indicates that there is an increase in the bearing capacity of the stabilized soil is not only due to the hydration of cement with time but optimum rubber content. An increase in CBR value can significantly reduce the total thickness of the pavement. Similar results were reported by (KoteswaraRao et al., [9]).

\subsection{Volumetric reduction of pavement}

The Indian Road Congress has recommended a CBR design chart shown in fig 4. Different curves A, $\mathrm{B}, \mathrm{C}, \mathrm{D}, \mathrm{E}, \mathrm{F}$ and $\mathrm{G}$ have been given based on volume of commercial vehicles shown in table 3 . In order to design a pavement by CBR method, first the soaked CBR value of soil subgrade is evaluated. Then the appropriate design curve is chosen by taking the anticipated traffic into consideration. The design curve can be selected by using the formula,

$\mathrm{A}=\mathrm{P}(1+\mathrm{r})^{(\mathrm{n}+10)}$

Where, $A=$ number of heavy vehicles per day for design

$\mathrm{P}=$ number of heavy vehicles for design at least count

$r=$ annual rate of increase of heavy vehicles

$\mathrm{n}=$ design life of pavement. 


\subsubsection{Design of flexible pavement for black cotton soil}

Design of flexible pavement for black cotton soil without stabilization,

Number of commercial vehicles per day $=1500$

Applicable CBR design curve $=\mathrm{E}$

Design CBR (soaked) for subgrade soil $=1.24 \%$

Hence, the pavement thickness (from Pavement thickness design chart) $=775 \mathrm{~mm}$

Design of flexible pavement for black cotton soil with stabilization,

Number of commercial vehicles per day $=1500$

Applicable CBR design curve $=\mathrm{E}$

Design CBR (soaked) for subgrade soil $=11.16 \%$

Hence, the pavement thickness (from Pavement thickness design chart) $=275 \mathrm{~mm}$

Total reduction in pavement thickness $775-275=500 \mathrm{~mm}$

Percentage reduction in pavement thickness $=64.51 \%$

\subsubsection{Design of flexible pavement for shedi soil}

Design of flexible pavement for shedi soil without stabilization,

Number of commercial vehicles per day $=1500$

Applicable CBR design curve $=\mathrm{E}$

Design CBR (soaked) for subgrade soil $=2.63 \%$

Hence, the pavement thickness (from Pavement thickness design chart) $=750 \mathrm{~mm}$.

Design of flexible pavement for shedi soil with stabilization,

Number of commercial vehicles per day $=1500$

Applicable CBR design curve $=\mathrm{E}$

Design CBR (soaked) for subgrade soil $=13.79 \%$

Hence, the pavement thickness (from Pavement thickness design chart) $=250 \mathrm{~mm}$

Total reduction in pavement thickness $750-250=500 \mathrm{~mm}$

Percentage reduction in pavement thickness $=66.66 \%$

\section{Conclusions}

1) The unconfined compressive strength and California bearing ratio increases with the increase in cement content at an optimum fiber content of $5 \%$.

2) The unconfined compressive strength has increased from $15 \mathrm{KPa}$ to $74 \mathrm{Kpa}$ for $2 \%$ cement and $246 \mathrm{Kpa}$ for $4 \%$ cement for black cotton soil.

3) Shedi soil shows an increase in unconfined compressive strength from $59.40 \mathrm{KPa}$ to $201 \mathrm{KPa}$ whereas for $4 \%$ cement content it has increased to $328 \mathrm{KPa}$.

4) Deep foundations and raft foundations for structures on soil with low bearing capacity can be replaced by shallow foundation with soil stabilized by shredded rubber waste.

5) California bearing ratio (soaked) has increased from $1.24 \%$ to $11.16 \%$ for $4 \%$ cement which reduces pavement thickness by $64.51 \%$ for black cotton soil.

6) Shedi soil shows an increase in California bearing ratio (soaked) from $2.63 \%$ to $13.79 \%$ which reduces pavement thickness by $66.66 \%$.

7) Increases in CBR value significantly reduce the total thickness of the pavement and hence the total cost involved in the project.

8) Shredded rubber fiber can be considered as a good reinforcement material.

For further investigation, laboratory tests can be carried in the same way with other stabilizing agents and shredded rubber tyre.

\section{References}

[1] Yilmaz, A. and Degirmenci, N. (2009). Possibility of using waste tire rubber and fly ash with Portland cement as construction materials. Waste Management, 29 (5) 1541-1546

[2] Lee, K.H. and Lee, S. (2002). Mechanical properties of weakly bonded cement stabilized kaolin. KSCE Journal of Civil Engineering, Vol. 6 (4) 389-398

[3] Bell F.G.,Stabilization and treatment of clay soils with lime. Journal of Ground engineering,Vol 21(1) 1988,pp.10-15.

[4] Chen, H., and Wong, Q., The behavior of soft soil stabilization using cement.Bulletin of Engineering Geology and the Environmenta by Springerlink. 2006.

[5] Croft, J.B.,.The Influence of Soil Mineralogical Composition on Cement Stabilization.Geotechnique, London, England, No.17, 1967,pp119-135.

[6] Al-Rawas, A.A., Taha, R., Nelson, J.D., Al-Shab., T. and Al-Siyabi, H., A Comparative Evaluation of Various Additives Used in the Stabilization of Expansive Soils, Geotechnical Testing Journal, GTJODJ, ASTM No. 25 (2) 2002,pp199-209. 
[7] Peech, M., HydrogenIon activity.Methods Soil Analysis, Agronomy No.9, Chapter 60, American Society of Agronomy, Madison, Wisc, 1965.

[8] Meei-Hoan Ho., Chee-Ming Chan., The potential of using rubber chips as a soft clay stabilizing enhancing agent. Journal of Applied Modern Science,Vol.4. 2010,pp.122-131.

[9] KoteswaraRao., ShilpaDevi,G.N., Pranav,P.R., A laboratory study on the influence of rubber strips on the improvement of CBR values of expansive soil. International Journal of Engineering Science \& Advanced Technology, Vol.2. 2012,pp.12-17.

[10] Subramanian,R.M., Jeyapriya,S.P., Study of effect of waste tyres in flexible pavement system. Indian Geotechnical Society Chennai chapter, 2009 ,pp. 19-23.

[11] Ayothiraman,R., Abilash Kumar Meena.,. Improvement of subgrade soil with shredded waste tyre chips. Proceedings of Indian Geotechincal Conference kochi, Paper no H -003. 2011, pp.365-368.

[12] Zornberg.G.J.,Costa,Y.D., Vollenweider,B.,. Performance of prototype embankment built with tyre shreds and nongranular soil. Journal of Transportation research Board, Vol.1847. 2004, pp.70-77.

[13] Prasad,D.S.V., Prasad Raju,G.V.R., Performance of waste tyre rubber on model flexible pavement. Asian Research Publishing Network Journal on Applied Science,Vol.4,2009,pp.89-92.

[14] Ayothiraman,R., Abilash Kumar Meena.,. Improvement of subgrade soil with shredded waste tyre chips. Proceedings of Indian Geotechincal Conference kochi, Paper no H -003. 2011, pp.365-368. 